\title{
Nitrogen Deficiency in Palms ${ }^{1}$
}

Timothy K. Broschat ${ }^{2}$

\section{Symptoms}

Nitrogen deficiency begins as a uniform light green discoloration of the oldest leaves (Figure 1). As the deficiency progresses, younger leaves will also become discolored. When the entire crown except for the spear leaf is affected, leaves will become progressively lighter in color and may be nearly white (Figure 2). Growth virtually stops when $\mathrm{N}$ deficiency is severe, but the palms may linger in this state for a considerable length of time. In older palms in the landscape or field, canopy size becomes greatly reduced, very light green in color, and the trunk will taper (pencil-pointing).

\section{Cause}

In most mineral soils, $\mathrm{N}$ deficiency is typically caused by insufficient $\mathrm{N}$ in the soil. However, substrates used in container production of palms often contain a high percentage of organic components such as bark or peat. Since these components have a high carbon to nitrogen ratio, the microbes that break them down require an external source of $\mathrm{N}$ to do so. These microbes very effectively compete with palm roots for any available $\mathrm{N}$ in the soil and are the primary reason why $\mathrm{N}$ deficiency is such a persistent problem in container production. Water soluble $\mathrm{N}$

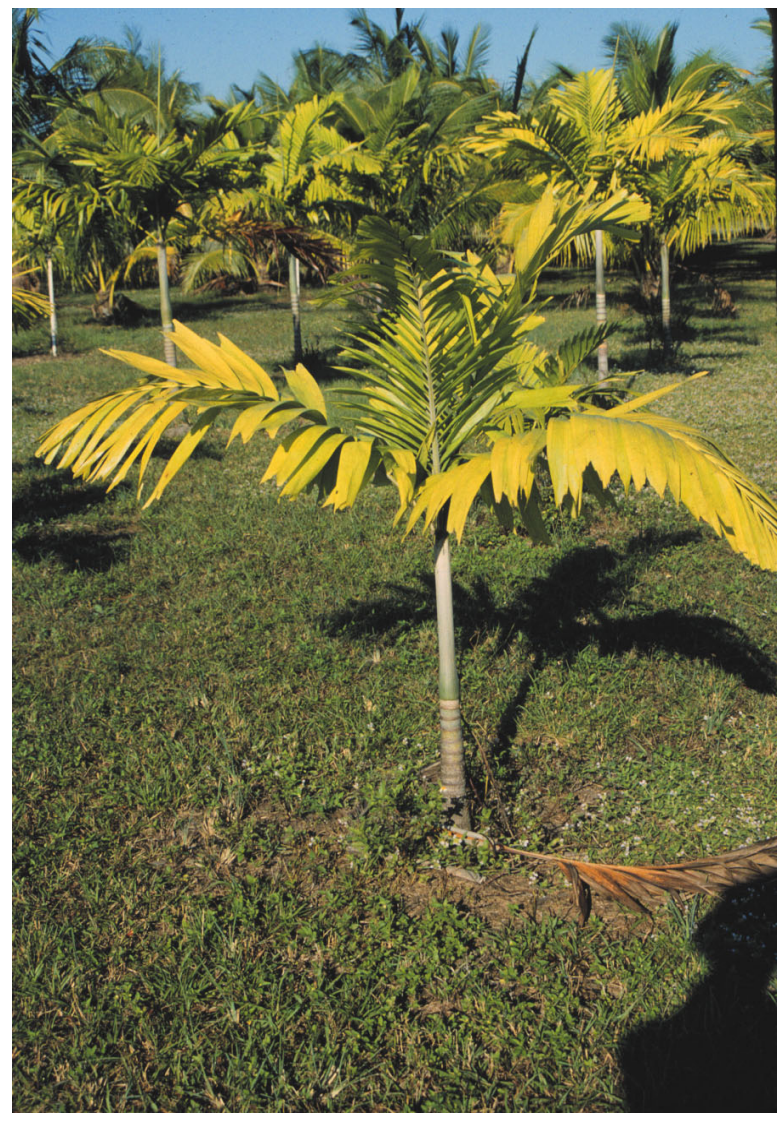

Figure 1. Nitrogen deficieny on Ptychosperma elegans (solitaire palm) showing uniformly discolored older leaves. Credits: T.K. Broschat

1. This document is ENH1016, one of a series of the Environmental Horticulture Department, Florida Cooperative Extension Service, Institute of Food and Agricultural Sciences, University of Florida. Original publication date September 2005. Visit the EDIS Web Site at http://edis.ifas.ufl.edu.

2. Timothy K. Broschat is Professor, Environmental Horticulture Department, Fort Lauderdale Research and Education Center, Institute of Food and Agricultural Sciences, University of Florida, Fort Lauderdale, FL 33314

The Institute of Food and Agricultural Sciences (IFAS) is an Equal Opportunity Institution authorized to provide research, educational information and other services only to individuals and institutions that function with non-discrimination with respect to race, creed, color, religion, age, disability, sex, sexual orientation, marital status, national origin, political opinions or affiliations. U.S. Department of Agriculture, Cooperative Extension Service, University of Florida, IFAS, Florida A. \& M. University Cooperative Extension Program, and Boards of County Commissioners Cooperating. Larry Arrington, Dean 


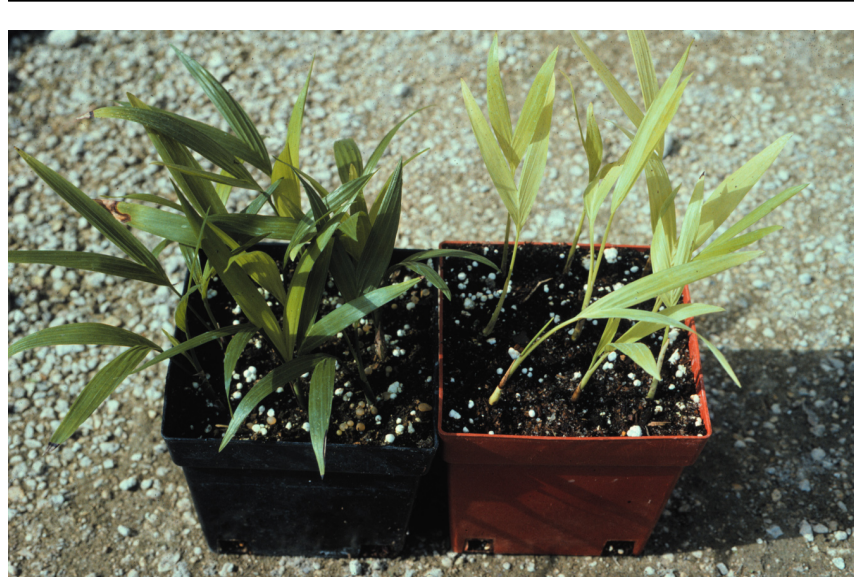

Figure 2. Nitrogen deficient Chamaedorea seifrizii (bamboo palm) seedlings on the right. Credits: T.K. Broschat

sources are also highly leachable in most container substrates, thus greatly compounding the problem.

\section{Occurrence}

Nitrogen deficiency is by far the most important deficiency encountered in container production of palms and all palm species are susceptible when grown in containers. However, in the field or landscape, $\mathrm{N}$ deficiency is relatively uncommon, and for most species of palms, $\mathrm{N}$ deficiency is not the primary limiting element. In Adonidia merrillii, Ravenea rivularis, Ptychosperma spp., and Veitchia spp. growing in the field or landscape, $\mathrm{N}$ deficiency is the most common nutrient deficiency. However, even in these species, it is seldom a serious problem.

\section{Diagnostic Techniques}

Nitrogen deficiency is easily diagnosed by symptoms alone, although leaf nutrient analysis can also be helpful. Nitrogen deficiency can be confused with $\mathrm{Fe}$ or $\mathrm{S}$ deficiency, although the chlorosis in those deficiencies is typically most severe on the youngest leaves. The reverse is true for $\mathrm{N}$ deficiency.

When sampling for leaf analysis, select 4 to 6 central leaflets from the youngest fully-expanded leaf. Soil analysis is not particularly useful for diagnosing palm nutrient deficiencies, since palm nutrient symptomology often bears little resemblance to soil nutrient profiles.

\section{Management}

Nitrogen deficiency in palms is easily prevented or treated. In container production, use of controlled-release fertilizers is highly recommended to reduce losses due to leaching. Injection of water-soluble $\mathrm{N}$ into irrigation water at a rate of 150 to $200 \mathrm{ppm}$ is an alternative, but research has generally shown that controlled-release fertilizers result in more rapid growth with less leaching loss of $\mathrm{N}$ into the environment. Although $\mathrm{N}$ can be taken up in either ammonium or nitrate form, most palms grow better with urea or ammonium than nitrate. However, a mixture of ammonium or urea and nitrate is excellent for palms. For container production, an analysis of approximately $18 \mathrm{~N}-6 \mathrm{P}_{2} \mathrm{O}_{5}-12 \mathrm{~K}_{2} \mathrm{O}$ is recommended.

In field production or in the landscape, $\mathrm{N}$ deficiency is rather uncommon and the rapid growth caused by high $\mathrm{N}$ fertilization can upset the nutrient balance within the palm. For that reason, fertilizers used for palms in the landscape or field nursery should have an analysis of about $8-2 \mathrm{P}_{2} \mathrm{O}_{5}-12 \mathrm{~K}_{2} \mathrm{O}+4 \mathrm{Mg}$ with micronutrients. Because water soluble $\mathrm{N}$ is readily leached through most soils in Florida, $100 \%$ of the $\mathrm{N}$ should be in controlled release form. Commonly used sources include sulfur-coated urea, urea-formaldehyde, resin-coated urea, or resin-coated ammonium salts. Fertilizers should be broadcast uniformly throughout the area under the canopy, or in landscape situations, throughout the entire landscape.

Existing $\mathrm{N}$ deficiencies in container or mineral soils can be corrected by using the fertilizers mentioned above. Unlike other nutrient deficiencies, $\mathrm{N}$-deficient leaves will usually regain their normal green coloration when appropriately fertilized. Foliar sprays with urea or ammonium or nitrate salts can also be used to quickly re-green $\mathrm{N}$-deficient palms.

\section{Selected References}

Broschat, T.K. 1984. Nutrient deficiency symptoms in five species of palms grown as foliage plants. Principes 28:6-14

Bull, R.A. 1961. Studies on the deficiency symptoms of the oil palm. 2. Macronutrient 
deficiency symptoms in oil palm seedlings grown in sand culture. J. West African Inst.

Oil Palm Res. 3:254-264.

Conover, C.A. and R.T. Poole. 1982. Influence of nitrogen source on growth and tissue nutrient content of foliage plants. (Abstr.) HortScience 17:518. 